\title{
Gomphothere proboscidean (Gomphotherium) from the late Neogene of Panama
}

\author{
Bruce J. MacFadden, ${ }^{1}$ Gary S. Morgan, ${ }^{2}$ Douglas S. Jones, ${ }^{1}$ and Aldo F. Rincon ${ }^{1}$ \\ ${ }^{1}$ Florida Museum of Natural History, University of Florida, Gainesville FL 32611, USA, 〈bmacfadd@ flmnh.ufl.edu $\rangle$; 〈dsjones@ @lmnh.ufl.edu $\rangle$; \\ $\langle$ arincon@ufl.edu〉 \\ ${ }^{2}$ New Mexico Museum of Natural History and Science, Albuquerque, NM 87104, USA, 〈gary.morgan1@ state.nm.us〉
}

\begin{abstract}
The proboscidean Gomphotherium is reported here from the Alajuela Formation of Panama. Gomphotherium was widespread throughout Holarctica during the Miocene, and the Panama fossil represents the extreme southernmost occurrence of this genus in the New World. Allocation of the Panama Gomphotherium to a valid species is impossible given both the fragmentary material represented and the taxonomic complexity of species assigned to this genus. In North America, Gomphotherium has a relatively long biochronological range from the middle Miocene ( $15 \mathrm{Ma})$ to early Pliocene ( $\sim \mathrm{Ma})$. Based on morphological comparisons, the Panama Gomphotherium is either middle Miocene, thus representing the earliest-known entry of this genus into Central America, or late Miocene/early Pliocene, which challenges the currently accepted middle Miocene age of the Alajuela Formation as it has been previously reported from Panama.
\end{abstract}

\section{Introduction}

The gomphotheres (Gomphotheriidae Hay, 1922) are an extinct family of elephant-like proboscideans that originated in the Old World and subsequently dispersed into the New World during the middle Miocene (Tedford et al., 2004). They were widespread in North America during the Miocene and Pliocene (Lambert and Shoshani, 1998), and are reported from several localities in Central America during the latter part of this interval. It is generally believed that they extended their range into South America during the late Pliocene and early Pleistocene as part of the Great American Biotic Interchange (McKenna and Bell, 1997; Mothé et al., 2012), although there is some suggestion that they dispersed into South America during the late Miocene (Campbell et al., 2000). As represented by the mammutid Zygolophodon Vacek, 1877, proboscideans first dispersed into North America during the late Hemingfordian North American Land Mammal Age (NALMA) at about 16.5 Ma (Prothero et al. 2008). Of relevance to this report, the gomphotheriid Gomphotherium Burmeister, 1837 first appears in North America at the beginning of the late Barstovian (Ba2) at about $15 \mathrm{Ma}$ (Tedford et al., 2004). Thereafter, gomphothere fossils are relatively common in North America until they become extinct at the end of the Pleistocene.

According to Lambert and Shoshani (1998), Gomphotherium was the most primitive member of the gomphotheriids in North America during the Miocene. This clade is represented by several occurrences in southern North America and Central America, with the latter including Guatemala, Honduras, El Salvador, and Costa Rica (Frick, 1933; Ferrusquía-Villafranca, 1978; Webb and Perrigo, 1984; Lucas and Alvarado, 2010; Laurito and Valerio, 2010; Aguilar and Laurito, 2011). Over the years, the gomphotheriids in Central America have had a confusing taxonomy represented by several different generic names (i.e., Aybelodon Frick, 1933; Blickotherium Frick, 1933; and Rhynchotherium Falconer, 1868), although Lucas and Alvarado (2010) recently referred them all to Gomphotherium sp. Given the taxonomic complexity of primitive gomphotheres (e.g., see discussion in Lambert and Shoshani, 1998), this conservative approach seems justified at present. An up-to-date revision of this group is certainly in order.

Although Gomphotherium is generally accepted to have dispersed into North America during the middle Miocene (Barstovian), Lucas and Alvarado (2011) asserted that this genus (sensu lato) did not disperse into Central America until the late Miocene (early Hemphillian). The discovery described here thus addresses the timing of this dispersal event in Central America.

In 1959, John M. Turner, presently an optometrist living in Hattiesburg, Mississippi, was a rising senior at Balboa High School in the former Canal Zone, Panama. During that summer, he collected the gomphothere tooth, described below, near the Madden Boy Scout Camp (Morton, 1977) along the shores of what was then called Lake Madden (now Lake Alajuela) in Panama (Fig. 1). During the Panama Canal Society meeting in Orlando, Florida, in July 2013, Dr. Turner brought this discovery to the attention of the senior author. Based on subsequent correspondence with Dr. Turner, in January 2014, MacFadden, Jones, and Rincon located the site of the now defunct Madden Boy Scout Camp as well as the approximate location $( \pm \sim 0.5 \mathrm{~km})$ and stratigraphic context where Turner discovered the tooth.

Although fossil proboscideans were widespread in Central America during the Pleistocene, including several localities in 


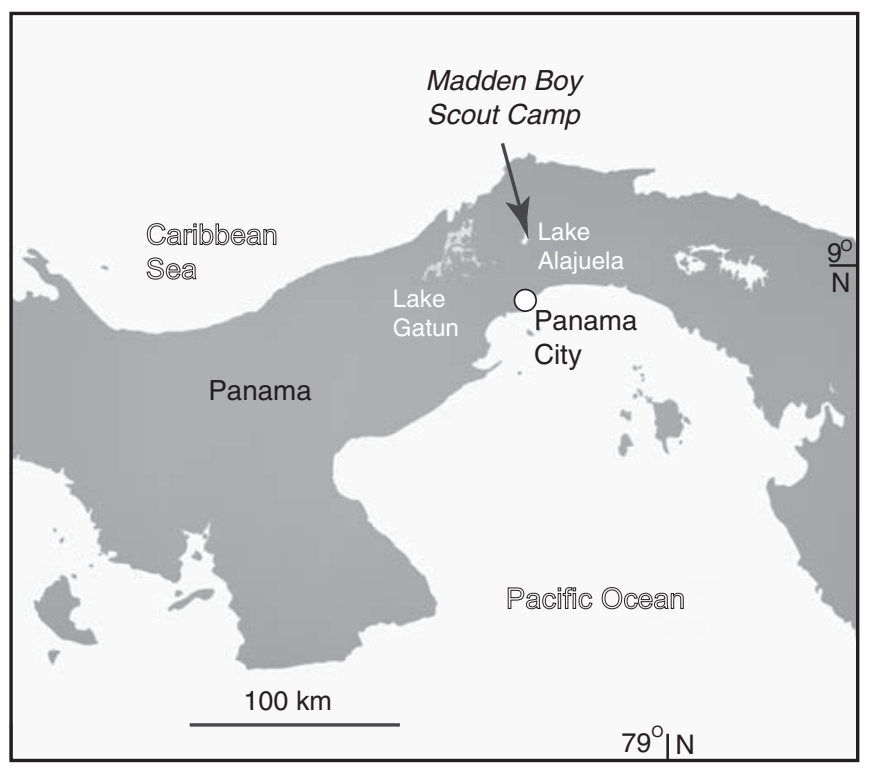

Figure 1. Map showing fossil collecting location, the now defunct Madden Boy Scout Camp, Lake Alajuela, Panama Province, Panama.

Panama (Pearson 2005; Morgan personal observation), no occurrences have been reported for pre-Pleistocene deposits in Panama. Given the rarity of gomphothere proboscideans in southernmost Central America during this time, the purpose of this paper is to describe this discovery, discuss its taxonomic position, and highlight its biogeographic and temporal significance during the Miocene.

\section{Systematic paleontology}

The following abbreviations are used in the text for institutional acronyms, all of which were used during this study:

AMNH F:AM: Frick American Mammals, part of the Vertebrate Paleontology collection, American Museum of Natural History, New York, NY; AMNH FM: Fossil Mammal Collection, American Museum of Natural History, New York, NY; NMMNH: New Mexico Museum of Natural History and Science, Albuquerque; TMM: Texas Memorial Museum, Vertebrate Paleontology Laboratory Collections, University of Texas, Austin; UF: Vertebrate Paleontology Collection, Florida Museum of Natural History, University of Florida, Gainesville; and USNM: United States National Museum of Natural History, Smithsonian Institution, Washington, D.C.

The complex dental nomenclature and homologies of proboscideans follow Tassy (1996a). Although the term North America is frequently used to include both North and Central America, in this paper, these geographic regions are distinct, with the boundary between the two at the southern border of Mexico.

Class Mammalia Linnaeus, 1758

Order Proboscidea Illiger, 1811

Family Gomphotheriidae Hay, 1922

Genus Gomphotherium Burmeister, 1837

Gomphotherium sp.

Figures 2.1-2.4
Material.-UF 294322, partial left $3^{\text {rd }}$ lower molar (m3).

Occurrence.-Collected by John M. Turner in 1959 from outcrops along Lake Alajuela (previously called Lake Madden) near the now defunct Madden Boy Scout Camp (Morton, 1977), former Canal Zone, Panama, now Chagres National Park, Panama Province (Fig. 1). Although previously assigned to the upper part of the Gatuncillo Formation (Woodring, 1957), Stewart et al. (1980) assigned outcrops along Lake Madden (= Alajuela) to the upper part of the lower Miocene Alajuela Formation (see further discussion below). Approximate location found in January 2014 is lat. $9.21236^{\circ}$, long. $-79.59358^{\circ}$. The uncertainty of this location based on the description provided by Dr. Turner is approximately $\pm 0.5 \mathrm{~km}$ along outcrops of the Alajuela Formation exposed along the shore of Lake Alajuela.

Description.-This specimen preserves the posterior half of the tooth (Fig. 2); including the posterior portion of the second transverse lophid, and the complete third and fourth lophids, followed by the hypoconulid. Identification of the tooth as an $\mathrm{m} 3$ is based on the tapering of the tooth posteriorly and the presence of a hypoconulid or half lophid on the posterior margin and a complete but transversely narrow fourth lophid. The $\mathrm{m} 3$ is moderately worn. The second and third lophids are in medium to early wear, respectively, and the fourth lophid is unworn. The enamel is relatively thick. Measurements of enamel thickness are $7.2 \mathrm{~mm}$ on the labial margin of the third lophid and $6.4 \mathrm{~mm}$ on the lingual margin of the third lophid. The enamel surface is smooth and uncomplicated, with essentially no development of plications or accessory cuspules or conulids. The tooth is relatively low crowned, or bunodont, with a crown height of $32.3 \mathrm{~mm}$ measured on the lingual margin of the third lophid and $31.6 \mathrm{~mm}$ on the lingual margin of the fourth lophid. On the occlusal surface of the third lophid, the labial side has a characteristic larger pretrite cuspid developed into a trefoil and lingually a smaller simple bunodont posttrite cuspid. The fourth lophid is less worn, i.e., with the thick enamel not breached, and contains a larger labial pretrite cuspid and smaller lingual posttrite cuspid. Although incompletely preserved, the second lophid clearly possesses a well-developed pretrite trefoil that contacts the anterior portion of the trefoil on the third lophid. The hypoconulid or posteriormost half lophid consists of two very small rounded conulids positioned on either side of the midline on the posterior margin of the $\mathrm{m} 3$. Prominent horizontal or subhorizontal enamel growth increments are developed on the crown, e.g., on the posterior face of the fourth lophid. So far as can be determined from the state of preservation, a cingulum appears to be poorly developed, or absent. The robust posterior root is preserved.

This tooth is at the smaller end of the range relative to other specimens of Gomphotherium studied and measured (Fig. 3). The anterior-posterior length from the posteriormost part of the crown to the anterior border of the third pretrite trefoil (see landmarks in Fig. 2) is $66.7 \mathrm{~mm}$; the greatest transverse width across the third lophid is $58.1 \mathrm{~mm}$.

Comparisons.-Of the collections examined during this study, UF 294322 compares favorably with specimens currently assigned to Gomphotherium from the middle Miocene (Barstovian) to latest Miocene/earliest Pliocene (latest Hemphillian) range of 

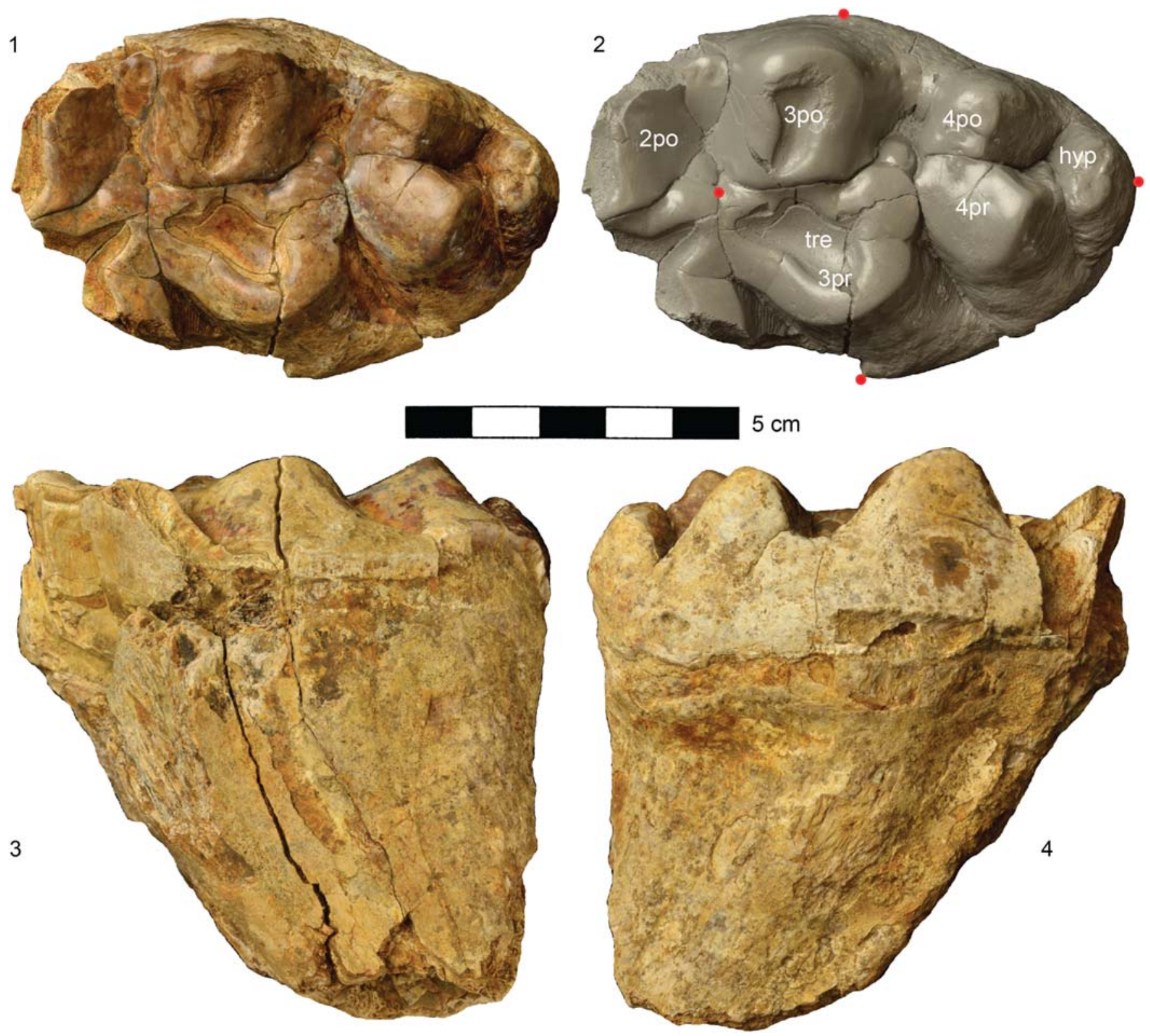

Figure 2. Gomphotherium sp., L m3, UF 294322, from the Alajuela Formation, Lake Alajuela, Panama Province Panama. (1) occlusal view; (2) occlusal view of cast; (3) labial (external) view; (4) lingual (internal) view. Red dots on the cast (2) represent measurement landmarks. These measurements represent the anterior-posterior length from the posterior-most part of the crown to the anterior border of the third pretrite trefoil and the greatest transverse width across the third lophid. Abbreviations: $2 \mathrm{po}, 2^{\text {nd }}$ postrite cusp; $3 \mathrm{pr}, 3^{\text {rd }}$ pretrite trefoil; $3 \mathrm{po}, 3^{\text {rd }}$ postrite cusp; $4 \mathrm{pr}, 4^{\text {th }}$ pretrite trefoil; 4 po, 4 postrite cusp; hyp, hypoconulid; tre, trefoil.

this genus in the New World. Although the major characters of gomphothere taxonomy include the morphological evolution of the tusks, certain diagnostic characters of the $\mathrm{m} 3$ and its size are relevant in the comparisons made with the following specimens below.

(1) Middle Miocene (Barstovian) of Maryland and Texas. In general, size (Fig. 3), tetralophodonty, development of the dental pattern (e.g., lophids and distinctive $\mathrm{m} 3$ hypoconulid), and relative hypsodonty, UF 294322, are similar to Gomphotherium calvertensis Gazin and Collins, 1950 from the Calvert Formation (USNM 12134, cast), Chesapeake Bay region of Maryland, and G. cimarronis Hay, 1925 (TMM 40775-1, cast) from the Cold Spring Fauna of the Texas Gulf Coastal Plain. All three of these Gomphotherium specimens are at the smallest end of the size range for this genus as it is known throughout Holarctica.

(2) Late Miocene/early Pliocene (Hemphillian) of Honduras and Florida. Gomphotheres have been described from classic late Miocene localities in Honduras (Frick 1933) and from the early Hemphillian Gracias Formation (Webb and Perrigo 1984). Two specimens from Honduras can be compared with the $\mathrm{m} 3$ of Gomphotherium from Panama. These include the type (AMNH F: AM 27075) and referred specimen (AMNH F:AM 27067) of "Aybelodon" hondurensis (sensu Frick, 1933), which has most recently been considered Gomphotherium hondurensis (Lucas and Alvarado, 2010; Aguilar and Laurito, 2011). Despite being similar in general dental morphology, the Honduras gomphothere 


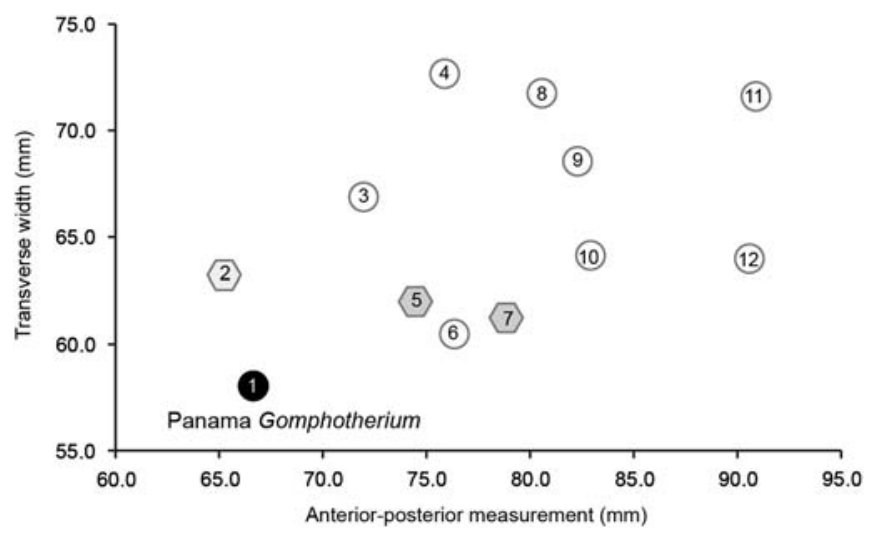

Figure 3. Measurements of selected specimens of $\mathrm{m} 3$ of Gomphotherium sp. from North and Central America. Shaded hexagon symbols represent type specimens. In addition to UF 294322 (black circle), these include relevant specimens of $G$. calvertensis (Gazin and Collins, 1950), G. cimarronis (see Hay, 1925), G. hondurensis (Frick, 1933 et seq.), and G. simplicidens (e.g., Webb et al., 2008). The landmarks for these measurements are depicted in Fig. 2. The specimens measured are: (1) Gomphotherium sp. from Panama, UF 294322 (described in this report); (2) type, G. cimarronis, Texas, cast of Texas A\& M 2121; (3) G. simplicidens, Florida, UF 123840; (4) Gomphotherium sp., New Mexico, NMMNH 19204; (5) type Serridentinus simplicidens, Florida, AMNH FM 1907A; (6) G. calvertensis, Maryland, USNM 12134 (cast); (7) type Aybelodon hondurensis, Honduras, AMNH FM 27075; (8) G. simplicidens, Florida, UF 93628; (9) "Trilophodon" sp., Texas, TMM 30936-289; (10) G. simplicidens, Florida, UF 28972; (11) G. hondurensis, Honduras, AMNH FM 27067; (12)?G. cf. hondurensis, Florida, AMNH FM 26807.

material appears to be significantly larger than Gomphotherium from Panama (Fig. 3). Likewise, the Panama Gomphotherium m3 compares favorably in general dental morphology with those of the small, late-surviving species, G. simplicidens (Osborn, 1923) from Fort Pierce, Florida and the latest Hemphillian (Hh4) Whidden Creek Local Fauna of the Bone Valley phosphate mining district of central Florida (Webb et al. 2008). However, relative to Gomphotherium sp. from Panama, G. simplicidens from Florida appears to be larger (Fig. 3), and as represented in AMNH FM 1907A, the cingulid is better developed.

The selection of species that are compared here includes key specimens important to understanding the generic allocation of the specimen from Panama. Additional comparisons could be made, for example, with the various species of gomphotheres, largely undescribed since Frick (1933) from New Mexico, and relevant material from western United States, including Oregon (Downs, 1952) and California (e.g., Barstow and Blackhawk Ranch). Nevertheless, the intent of the above-referenced comparisons is not to be exhaustive given the fragmentary nature of the single tooth form Panama.

\section{Discussion}

Taxonomic assignment.-Gomphotherium is a primitive member of the gomphothere radiation, which likely represents a grade, or horizontal, paraphyletic taxon, and encompasses considerable intra- and interspecific variation across its wide range in the northern hemisphere (Tobien, 1972; 1973; Tassy, 1996b; Lambert and Shoshani, 1998). This genus is characterized by the $\mathrm{m} 3$ with three to five lophids, relatively simple bunodont enamel (few accessory cuspids or conulids), trefoils only developed on the pretrite half of the cheek teeth (single trefoiling), and oval (not flattened or spatulate) lower tusks, the latter of which are obviously not represented in UF 294322 (Lambert and Shoshani, 1998). The diagnostic characters of the $m 3$ are found in UF 294322 and thus justify the allocation of the Panama fossil to the genus Gomphotherium.

As Heckert et al. (2000) previously lamented, a complex array of Gomphotherium species have been described in the literature over the past century. Tobien (1973) synonymized most North American species of Gomphotherium with G. productum Cope, 1877, originally described from the middle Miocene (late Barstovian) of New Mexico. Nevertheless, many subsequent workers have not followed this reduction in the number of recognized, potentially valid species. Realizing the immense taxonomic complexity of this genus in North America, Lambert and Shoshani (1998) combined 14 nominal species together as Gomphotherium sp. In addition, some recent authors still refer to the Central American species as G. hondurensis (e.g., Lucas and Alvarado, 2010; Aguilar and Laurito, 2011), which until recently was referred to the gomphothere genus Rhynchotherium Falconer, 1868 (e.g., Webb and Perrigo, 1984). Given this taxonomic complexity, lack of some of the diagnostic characters (of the tusk), and similarly close comparisons with $G$. calvertensis, $G$. cimarronis, G. hondurensis, and $G$. simplicidens described above, we conclude that it is not possible to make a definitive specific assignment for UF 294322 from Panama.

As far as can be documented, the Madden specimen of Gomphotherium is the only known pre-Pleistocene occurrence of proboscideans in Panama before the reported occurrence of Cuvieronius tropicus from the Azuero peninsula and Pearl Islands (Pearson, 2005; Morgan personal observation). Another undescribed record of cf. Gomphotherium sp., is USNM 244508 , represented by a subconical partial anterior tusk. The associated museum catalog data indicates that this specimen was collected from the shallow marine Gatun Formation near Cativa on the Trans-isthmian Highway, near the Caribbean coast east of Colon. Geochemical analysis of this specimen using rare earth elements (MacFadden, unpublished data) yielded a high degree of organics and failed to confirm its provenience from the Gatun Formation.

Stratigraphic and paleoecological context.-The Gomphotherium tooth from Panama was collected from outcrops along Lake Alajuela (previously Lake Madden). Woodring (1957) mapped relevant outcrops along the shore of Lake Madden as pertaining to the lower to middle Miocene Caimito Formation (including the Alajuela Member), whereas Stewart et al. (1980) mapped these as the upper member of the upper middle Miocene Alajuela Formation, consisting of tuffaceous sandstones, calcareous sandstones, and limestones.

In January 2014, we found the approximate location ( \pm ca. $0.5 \mathrm{~km}$ ) where the gomphothere was collected along the shore of Lake Alajuela. Although the lake level was relatively high at the time (covering potentially relevant exposures), sediments likely pertaining to the upper Alajuela Formation cropped out at the water line. These marine sediments are highly fossiliferous. During our brief field survey, we found a tooth of the shark Hemipristis serra Agassiz, 1843 as well as invertebrates including molds, casts, and several species of fossil marine gastropods 
such as Turritella Lamarck, 1799, Conus Linneaus, 1758, and numerous cerithids. In addition, molds of infaunal and epifaunal bivalves (e.g., cardiids, pectinids) were common, as were molds of shallow-burrowing echinoids. The invertebrate fossils represent a fairly diverse benthic fauna that probably inhabited a well-oxygenated, shallow-marine paleoenvironment. In addition, our field crews have since returned to the same general location on several occasions as part of ongoing field investigations and found additional fossils. Once these fossils are described, they will further elucidate the biostratigraphic context and paleobiogeographic significance of this unit.

The presence of terrestrial mammal remains interbedded in shallow-marine sedimentary environments is not uncommon in the Panama stratigraphic sequence during the Miocene. For example, MacFadden et al. (2010) described the presence of the early Miocene peccary "Cynorca" occidentale Woodburne, 1969 from sediments interpreted to represent a marginal-marine facies, or a distal distributary (Kirby et al., 2008) of the upper part of the Culebra Formation.

Temporal and biogeographic significance.-The genus Gomphotherium was widespread in the Old World during the early Miocene (Tobien, 1973) and dispersed into North America during the middle Miocene at about $15 \mathrm{Ma}$ (Lambert and Shoshani, 1998; Tedford et al., 2004). The exact species of Gomphotherium that represents the initial dispersal is still up for debate (e.g., see different points of view in Gazin and Collins, 1950; Downs, 1952; and Tobien, 1973). According to Tedford et al. (2004), the first appearance of Gomphotherium defines the beginning of the late Barstovian (Ba2) North American Land Mammal Age at about $15 \mathrm{Ma}$. After this time, Gomphotherium is widespread in North America until the late Miocene, although it persists into the earliest Pliocene of Florida, represented by the species $G$. simplicidens. As described previously, Gomphotherium has been reported from several localities in Central America, including Guatemala, Honduras, El Salvador, and Costa Rica (Lucas and Alvarado, 2010; Laurito and Valerio, 2010; Aguilar and Laurito, 2011). As far as can be determined, all of these localities are of late Miocene (Hemphillian) age. Lucas and Alvarado (2010) therefore posited that Gomphotherium did not disperse into Central America until the Hemphillian, which according to Tedford et al. (2004) would be after $\sim 8.5 \mathrm{Ma}$. The occurrence of Gomphotherium in Panama is therefore relevant to an understanding of the dispersal and biogeography of this genus into Central America.

Gomphotherium from Panama has affinities with described species that range in age from late Barstovian ( $\mathrm{Ba} 2)$ to latest Hemphillian (Hh4) NALMA. With regard to Gomphotherium from Lake Alajuela, two possible scenarios currently exist for the age and significance of this occurrence from Panama and are presented below.

Scenario 1 suggests that Gomphotherium from Panama is middle Miocene (Barstovian) in age. This makes it similar to Barstovian localities containing Gomphotherium examined during this study, e.g., the Chesapeake Bay Fauna (Calvert Formation) from Maryland and the Cold Spring Fauna (Fleming Formation) of the Texas Gulf Coast. This hypothesis is also consistent with the middle Miocene age of the Alajuela Formation, as inferred from the superpositional relationships depicted on the geological map of Panama (Stewart, 1980). It is important to note here that based on the assumption that the Alajuela Formation underlies the Gatun Formation (this cannot be documented in the field), which is otherwise dated at between 11.2 and 8.5 Ma (Hendy, 2013), then the Alajuela Formation is older than 11.2 Ma. This scenario would therefore constrain the age of the Panama Gomphotherium to between $15 \mathrm{Ma}$ (its earliest occurrence in the New World; Tedford et al., 2004) and 11.2 Ma. The problem with this scenario is that it is inconsistent with that of Lucas and Alvarado (2010), which posited that Gomphotherium did not disperse into Central America until the early Hemphillian, i.e., after about 8.5 to $7 \mathrm{Ma}$.

Scenario 2 suggests that based on comparisons with late Miocene/early Pliocene (Hemphillian) Gomphotherium hondurensis from Honduras and G. simplicidens from Florida, the presence of Gomphotherium in Panama is consistent with the age of the early Hemphillian dispersal event into Central America posited by Lucas and Alvarado (2010). The problem with this scenario, therefore, is that it challenges the accepted superpositional relationships of the underlying Alajuela and overlying Gatun Formation (Stewart, 1980). Thus, if scenario 2 is correct, then the Alajuela is late, not middle, Miocene, and younger than the Gatun, whose upper boundary is constrained at 8.5 Ma (Hendy, 2013).

\section{Significance and concluding comments}

Although it might be tempting to refer the Panama discovery to an existing species, the named species of Gomphotherium from the New World are in a somewhat confusing state. Furthermore, with only a single partial $\mathrm{m} 3$ available from Panama, many of the important species-level diagnostic characters are not preserved. We therefore do not to assign it to a species at this time. This also follows Lambert and Shoshani (1998) in which all North American occurrences are referred to Gomphotherium sp.

Resolution of the two competing temporal scenarios will require additional field discoveries of biochronologically diagnostic fossils, and/or associated chronological calibrations from the Alajuela Formation. In either event, the occurrence of Gomphotherium from Panama is an important discovery, certainly from a paleobiogeographic point of view. The middle to late Miocene is a complex time in the evolution of New World tropical mammals before the Great American Biotic Interchange. The discovery of Gomphotherium described here further documents the ancient mammalian biodiversity in the New World tropics.

Our recent field reconnaissance indicates the possibility of many more suitable exposures of the Alajuela Formation during lowered lake levels. These outcrops thus provide the potential to elucidate our understanding of not just Gomphotherium, but other taxa of biochronologically diagnostic land mammals from the southernmost extent of the North American faunal province during the Miocene.

\section{Acknowledgments}

We primarily thank J. M. Turner of Hattiesburg, Mississippi, who collected the tooth in 1959, and brought it to the attention of the senior author. We also thank C. Jaramillo (Smithsonian Tropical Research Institute) for logistical support and S. Moran for taking 
the photos in Figure 2. M. Coombs (Amherst, Massachusetts), A. Hendy (Gainesville), R. Hulbert, Jr. (Gainesville), D. Mothé (Rio de Janiero, Brazil), J. Pinto (Chagres National Park, Panama), R. Portell (Gainesville), P. Tassy (Paris, France), A. Wood (Gainesville), and M. Woodburne (Flagstaff, Arizona) for helpful advice and input. We also thank the American Museum of Natural History, University of Texas Vertebrate Paleontology Laboratory (formerly part of TMM), and the US National Museum of Natural History for access to their collections: This study is part of the PCP (Panama Canal Project) PIRE (Partnerships in International Research and Education) and supported by US National Science Foundation grant 0966884 (OISE, EAR, DRL).

\section{References}

Agassiz, L., 1843, Recherches Sur Les Poissons Fossiles, Tome III (livr. 15-16). Neuchatel, Switzerland, Imprimérie de Petitpierre.

Aguilar, D.H., and Laurito, C.A., 2011, Nuevo registro de Gomphotherium hondurensis (Frick, 1933) (Proboscidea, Gomphoteriidae [sic.]) para el Mioceno Superior de El Salvador, América Central: Revista Geológica de América Central, v. 45, p. 95-100.

Burmeister, C., 1837, Handbuch der Naturgeschichte. Zum Gebrauch bei Vorlesungen entworfen. Zweite Abteilung, Zoologie, T. C. F. Enslin, Berlin, xvill $+302 \mathrm{p}$.

Campbell, K.E., Frailey, C.D., and Romero-Pittman, L., 2000, The late Miocene gomphothere Amahuacatherium peruvium (Proboscidea: Gomphotheriidae) from Amazonian Peru: implications for the Great American Faunal Interchange: Instituto Geológico Minero y Metalúrgico [Péru], Serie D, Estudios Regionales, Boletín 23, p. 1-152.

Downs, E., 1952, A new mastodont from the Miocene of Oregon with remarks on Gomphotherium [sic.]: University of California Publications in Geological Sciences, v. 29, p. 1-20.

Falconer, H., 1868, Paleontological Memoirs. Volume II: 74-75, London.

Ferrusquía-Villafranca, I., 1978, Distribution of Cenozoic vertebrate faunas in middle America and problems of migration between North and South America: Instituto de Geología, Universidad Nacional Autonoma México, v. 101 , p. $193-329$.

Frick, C., 1933, New remains of trilophodont-tetrabelodont mastodons: Bulletin of the American Museum of Natural History, v. 59, p. 505-652.

Gazin, C.L., and Collins, R.L., 1950, Remains of land mammals from the Miocene of the Chesapeake Bay Region: Smithsonian Miscellaneous Collections, v. 116, no. 2, p. 1-21.

Hay, O.P., 1922, Further observations on some extinct elephants: Proceedings of the Biological Society of Washington, v. 35, p. 97-102.

Hay, O.P., 1925, On remains of mastodons found in Texas, Anacus brazosius and Gomphotherium cimarronis [sic.]: Proceedings of the United States National Museum, v. 66, no. 2572, 4 plates, p. 1-15.

Heckert, A.B., Lucas, S.G., and Morgan, G.S., 2000, Specimens of Gomphotherium in the New Mexico Museum of Natural History and Science and the species-level taxonomy of North American Gomphotherium: New Mexico Museum of Natural History and Science Bulletin, v. 16, p. 187-194.

Hendy, A., 2013, Spatial and stratigraphic variation of marine paleoenvironments in the middle and upper Miocene Gatun Formation, Isthmus of Panama: Palaios, v. 28, p. 210-227.

Illinger, C., 1811, Prodromus systematis mammalium et avium additis terminis zoographicis utriusque classis: Berlin, Germany, C. Salfield.

Kirby, M.X., Jones, D.S., and MacFadden, B.J., 2008, Lower Miocene stratigraphy along the Panama Canal and its bearing on the Central American peninsula: PLoS One, v. 3(7): e2791, doi:10.1371/journal.pone.0002791

Lamarck, J.B., 1799, Prodrome d'une nouvelle classification des coquilles: Mémoires de la Société d'Histoire Naturelle de Paris, v. 74, 29 p.

Lambert, W.D., and Shoshani, J., 1998, Chapter 43, Proboscidea, in Janis, C.M., Scott, K.M., and Jacobs, L.L., eds, Evolution of Tertiary Mammals of North America, Volume 1, Terrestrial Carnivores, Ungulates, and Ungulatelike Mammals: Cambridge, UK, Cambridge University Press, p. 606-621.

Linnaeus, C., 1758, Systema Naturae per Regna tria Naturae, secundum Classes, Ordines, Genera, Species, cum Characteribus, Differentis, Synonymis, Locis (tenth edition): Stockholm, Sweden, Laurentii, Slavi, 824 p.
Lucas, S.G., and Alvarado, G.E., 2011, Fossil Proboscidea from the Upper Cenozoic of Central America: taxonomy, evolutionary and paleobiogeographic significance: Revista Geológica de América Central, v. 42 , p. $9-42$.

Laurito, C.A., and Valerio, A.L.Z., 2010, Los caballos fósiles de la formacíon Curré Cantón de Coto Brus, Costa Rica:San José, Museo Nacional Costa Rica, $131 \mathrm{p}$

MacFadden, B.J., Kirby, M.X., Rincon, A., Montes, C., Moron, S., Strong, N., and Jaramillo, C., 2010, Extinct peccary "Cynorca" occidentale (Tayassuidae, Tayassuinae) from the Miocene of Panama and correlations to North America: Journal of Paleontology, v. 84, p. 288-298.

McKenna, M.C., and Bell, S.K., 1997, Classification of Mammals Above the Species Level: New York, Columbia University Press, 631 p.

Morgan, G.S., personal observation.

Morton, E.S., 1977, Intratropical migration in the Yellow-Green Vireo and Piratic Flycatcher: The Auk, v. 94, p. 97-106.

Mothé, D., Avila, L.S., and Cozzul, M.A., 2012, The South American gomphotheres (Mammalia, Proboscidea, Gomphotheriidae): taxonomy, phylogeny, and biogeography: Journal of Mammalian Evolution, v. 20, p. 23-32, doi 10.1007/s10914-012-9192-3.

Osborn, H.F., 1923, New subfamily, generic, and specific stages in the evolution of the Proboscidea: American Museum Novitates, v. 99, 4 p.

Pearson, G.A., 2005, Late Pleistocene megafaunal deposits of the Isthmus of Panama and their paleoenvironmental implications: Caribbean Journal of Science, v. 41, p. 1-13.

Prothero, D.R., Davis, E.B., and Hopkins, S.B., 2008, Magnetic stratigraphy of the Massacre Lake beds (late Hemingfordian, early Miocene), northwest Nevada, and the age of the "Proboscidean Datum" in North America. Neogene Mammals: New Mexico Museum of Natural History and Science Bulletin, v. 44, p. 239-245.

Stewart, R.H., Stewart, J.L., and Woodring, W.P., 1980, Geologic map of the Panama Canal and vicinity, Republic of Panama: United States Geological Survey Miscellaneous Investigations Series Map I-1232, scale 1:100,000, 1 sheet.

Tassy, P., 1996a, Chapter 3. Dental homologies and nomenclature in the Proboscidea, in Shoshani, J., and Tassy, P. The Proboscidea: Evolution and Palaeoecology of Elephants and their Relatives: Oxford, Oxford University Press, p. 21-25.

Tassy, P., 1996b, Chapter 11. Growth and sexual dimorphism among Miocene elephantoids: the example of Gomphotherium angustidens, in Shoshani, J., and Tassy, P., The Proboscidea: Evolution and Palaeoecology of Elephants and their Relatives: Oxford, Oxford University Press, p. 92-100.

Tobien, H., 1972, Status of the genus Serridentinus Osborn 1923 (Proboscidea, Mammalia) and related forms: Mainzer Geowissenschaftliche Mitteilungen, v. 1 , p. $143-191$.

Tobien, H., 1973, On the evolution of mastodonts (Proboscidea, Mammalia) Part 1: The bunodont trilophodont groups: Notizblatt des Hessischen Landesamtes für Bodenforschung zu Weisbaden, v. 101, p. 202-276.

Tedford, R.H., Albright, L.B. III, Barnosky, A.D., Ferrusquía-Villafranca, I., Hunt, R.M. Jr., Storer, J.E., Swisher, C.C. III, Voorhies, M.R., Webb, S.D., and Whistler, D.P., 2004, Mammalian biochronology of the Arikareean through Hemphillian interval (late Oligocene through early Pliocene epochs), in Woodburne, M.O., ed., Late Cretaceous and Cenozoic Mammals of North America: Biostratigraphy and Geochronology: New York, Columbia University Press, p. 169-231.

Vacek, M., 1877, Uber Osterreichische Mastodonten und ihre Beziehungen zu den Mastodonarten Europas: Abhandlungen der Kaiserlich-königlichen Geologischen Reichsanstalt, Wien, v. 7, Heft, 4, p. 1-45.

Webb, S.D., Hulbert, R.C. Jr., Morgan, G.S., and Evans, H.F., 2008, Terrestrial mammals of the Palmetto Fauna (early Pliocene, latest Hemphillian) from the Central Florida Phosphate District: Natural History Museum of Los Angeles County Science Series, v. 41, p. 293-312.

Webb, S.D., and Perrigo, S.C., 1984, Late Cenozoic vertebrates from Honduras and El Salvador: Journal of Vertebrate Paleontology, v. 4, p. 237-254.

Woodburne, M.O., 1969, Systematics, biogeography, and evolution of Cynorca and Dyseohyus (Tayassuidae): Bulletin of the American Museum of Natural History, v. 141, p. 271-356.

Woodring, W.P., 1957, Geology and paleontology of Canal Zone and adjoining parts of Panama, Geological Survey Professional Paper 306-A, Washington DC, United States Government Printing Office, p. 1-239.

Accepted 17 July 2014 